\title{
ASSOCIATION BETWEEN KNOWLEDGE, ATTITUDE, NORM, AND FREE SEX BEHAVIOR AMONG UNIVERSITY STUDENTS IN SRAGEN, CENTRAL JAVA
}

\author{
Nugroho Priyo Handoko
}

Masters Program in Family Medicine, Sebelas Maret University

\begin{abstract}
Background: Premarital sex contradicts with religious values and social norms in Indonesia. Premarital sex is a major concern since it may lead to unwanted pregnancy and unsafe abortion, transmission of sexual transmitted disease and HIV/AIDS, and ultimately death. This study aimed to determine association between knowledge, attitude, norm, and free sex behavior among university students in Sragen, Central Java.

Subjects and Method: This was cross-sectional study, conducted at academies of nursing, midwifery, and health polytechnics, in Sragen, Central Java. A sample of 142 students were selected for this study at random. The dependent variable was free sex. The independent variables were knowledge, attitude, and social norm. The data were collected using questionnaire and analyzed by multiple logistic regression.

Results: Good knowledge in free sex $(\mathrm{OR}=0.37 ; 95 \% \mathrm{CI}=0.18$ to $0.77 ; \mathrm{p}=$ 0.008), positive attitude $(\mathrm{OR}=0.02 ; 95 \% \mathrm{CI}<0.01$ to $0.07 ; \mathrm{p}<0.001)$, and adherence to norm $(\mathrm{OR}=0.15 ; 95 \% \mathrm{CI}=0.07$ to $0.34 ; \mathrm{p}<0.001)$ were associated with lower risk of practicing free sex among students.

Conclusion: Good knowledge in free sex, positive attitude, and adherence to norm are associated with lower risk of practicing free sex among students.
\end{abstract}

Keywords: free sex, knowledge, attitude, norm

Correspondence: Nugroho Priyo Handoko. Masters Program in Family Medicine, Sebelas Maret University, Jl. Ir. Sutami 36 A, Surakarta 57126, Central Java. Email: handokon67gmail.com. 